\title{
Etiologic Role of Lactic Dehydrogenase Virus Infection in an Age-Dependent Neuroparalytic Disease in C58 Mice
}

\author{
JOHN F. NAWROCKI, LARRY R. PEASE, AND WILLIAM H. MURPHY' \\ The Department of Microbiology and Immunology, The University of Michigan School of Medicine, \\ Ann Arbor, Michigan 48109
}

Accepted March 5, 1980

\begin{abstract}
Lactic dehydrogenase virus (LDV) associated with transplantable line Ib lymphocytic leukemia in $\mathrm{C} 58 / \mathrm{Wm}$ mice, $\mathrm{K} 36$ lymphocytic leukemia in AKR/J mice, and the Gardner lymphosarcoma in $\mathrm{C} 3 \mathrm{H} / \mathrm{HeJ}$ mice elicited a fatal neuroparalytic disease when injected ip into 7- to 9-month-old X-irradiated indicator C58 mice. LDV associated with the WEHI-3B line of transplantable myelomonocytic leukemia or the Harding-Passey transplantable myeloma in $\mathrm{BALB} / \mathrm{c}$ mice failed to elicit the disease. Recipients of such tumor extracts were immune to rechallenge by line Ib-associated LDV. Tumor lines free of LDV failed to elicit the disease or immunize recipient mice to line Ib LDV challenge. The Plagemann (P-LDV), Riley (R-LDV), and Notkins (N-LDV) strains of LDV were less neuropathogenic than the line Ib-derived strain (Ib-LDV). Indicator C58 mice that survived infection by the P-LDV, R-LDV, and N-LDV strains were immune to rechallenge by Ib-LDV. Antiserum prepared in young C58 mice to Ib-LDV or R-LDV protected indicator C58 mice from Ib-LDV challenge. These results show that a common viral contaminant of transplantable tumors and virus stocks that ordinarily is not pathogenic elicits a fatal neurologic discase in genetically susceptible, immunosuppressed, C58 mice.
\end{abstract}

When young immunocompetant $\mathrm{C} 58$ mice are immunized with X-irradiated $(10,000 \mathrm{R})$ syngeneic line $\mathrm{Ib}$ malignant cells ( $\mathrm{Ib}$ cells) a strong protective response to transplanted leukemia is elicited (1) that is mediated by Thy 1.2 , Ia', T cells (2). However, when normal C58 mice 9 or more months of age receive a similar injection of $\mathrm{X}$-irradiated $\mathrm{Ib}$ cells (3) they develop a fatal paralytic neurologic disease characterized by an inflammatory destruction of motor neurons that is confined largely to the brain stem and cord (4). Paralysis begins at about 9 days after the injection of X-irradiated cells, reaches a peak at 13 to 17 days, and parallels motor neuron destruction (4). The histopathology of the disease is distinctive (4) in that the demyelination seen in other neurotropic mouse virus infections is absent and the white matter and peripheral nerves are free of lesions. The flaccid paralysis seen is not accompanied by ataxia, tremors, or seizures. In the naturally susceptible C58

${ }^{1}$ To whom reprint requests should be addressed. strain susceptibility correlates $(5,6)$ with an age-dependent loss in T-cell functions. The disease can be elicited in young C58 or AKR mice (5) providing that they are immunosuppressed by X irradiation or drugs 1 day before the ip injection of $\mathrm{X}$-irradiated Ib cells. The common inbred strains of mice $(5-7)$ are not susceptible whether they are young or old or immunosuppressed or not. Extensive efforts to implicate a conventional mouse virus or a neuropathogenic C-type virus in the disease (reviewed in Ref. (6), or to demonstrate an autoimmune basis for the disease, were unsuccessful (reviewed in Ref. (7)). These results suggested that either a constituent of Ib cells was neuroparalytic to C58 mice or that some unconventional virus associated with line Ib cells was the neuropathogenic agent. After the realization $(6,7)$ that only genetically susceptible immunosuppressed mice were suitable for tests, virus assays were repeated using highly susceptible X-irradiated C58 mice as indicator animals. We report here that LDV 
infection is an essential etiologic factor in the pathogenesis of this multifactorial disease in the naturally susceptible C58 strain. As discussed below, coinfection by N-tropic C-type retroviruses in mouse strains permissive for $\mathrm{N}$-tropic retrovirus replication appears to be of equal etiologic importance (see Ref. ( 7 ) and unpublished data).

For virus assays $10^{8}$ viable Ib cells prepared from the spleens of C58 mice moribund from transplanted line Ib leukemia were suspended in $0.5 \mathrm{ml}$ of Hanks' balanced salt solution (HBSS), sonicated $\left(10 \mathrm{kHz}\right.$ at $\left.25 \mathrm{~mA}, 4^{\circ}\right)$ using a Ratheon low-intensity DF 101 uscillator, and centrifuged at $100,000 \mathrm{~g}$ for $2 \mathrm{hr}$. The supernatant fluid was filtered through a $0.22-\mu \mathrm{m}$ filter, diluted in HBSS to contain $10 \mu \mathrm{g}$ protein $/ \mathrm{ml}$, and injected intraperitoneally (ip) as passage 1 into 6 -monthold C58 mice that had received $600 \mathrm{R}$ of whole-body X irradiation $24 \mathrm{hr}$ previously. Details of methodology are given in Ref. (5). For the second passage spleen cell suspensions were prepared from mice that were moribund from paralytic disease (14 to 17 days after the initial injection), pooled, and a cell-free extract was prepared as described for passage 1. All subsequent serial passages were done in the same way. Table 1 shows that a self-replicating filterable agent associated with $\mathrm{Ib}$ cells

TABLE 1

Neuropathogenicity of Spleen Cell Extracts FOR 6-MONTH-OLD X-IRRADIATED C58 MICE

\begin{tabular}{ccc}
\hline $\begin{array}{c}\text { Serial } \\
\text { passage }\end{array}$ & $\begin{array}{c}\text { Incidence of } \\
\text { paralysis or death }\end{array}$ & $\begin{array}{c}\text { Cumulative } \\
\text { dilution }\end{array}$ \\
\hline 1 & $6 / 6$ & $10^{-6}$ \\
2 & $6 / 6$ & $10^{-12}$ \\
3 & $7 / 7$ & $10^{-18}$ \\
4 & $3 / 13$ & $10^{-24}$ \\
5 & $7 / 7$ & $10^{-30}$ \\
6 & $7 / 7$ & $10^{-36}$ \\
\hline
\end{tabular}

"Cell-free filtrates were prepared as described in the text from spleen cells obtained from 6-month-old $\mathrm{X}$-irradiated C58 mice moribund from histologically confirmed motor neuron disease.

${ }^{b}$ Mice developed paralytic disease within 15 to 20 days after the ip injection $(1 \mathrm{ml})$ of each spleen cell extract. was implicated in the etiology of the disease. These results confirmed our preliminary findings $(z)$ and those reported concurrently by Martinez et al. (8).

Since Ib cells are known to contain an abundance of C-type virus particles (3), and might be contaminated with other mouse viruses as well $(9,10)$, it was essential to implicate the detected virus in the pathogenesis of the disease. Therefore a spectrum of tumors was assayed to determine whether the neuropathogenic virus was unique to Ib cells or ubiquitous in tumor cell lines. Because susceptibility to the disease currelated $(5-7)$ with the susceptibility of the C58 $\left(H-2^{\mathbf{k}}\right)$ and AKR/J $\left(H-2^{\mathrm{k}}\right)$ strains to spontaneous leukemia, tumors were selected for study that were lymphoid neoplasms of the $H-2^{\mathrm{k}}$ haplotype. Two $H$ - $2^{d}$ nonlymphoid tumors were used as controls. The high levels of neuropathogenic activity observed in the serum of C58 mice $24 \mathrm{hr}$ after the injection of Ib cells $(6,11)$, and unpublished studies by Martinez et al. (Ref. (8) and personal communication), suggested that LDV might be the neuropathogenic agent. The tumor cell lines listed in Table 2 therefore were tested both for their capacity to elicit paralytic disease in indicator C58 mice and for LDV activity. Sonicates of $10^{8}$ tumor cells were centrifuged at $3000 \mathrm{~g}$ for $10 \mathrm{~min}$, the supernatant fluid was diluted $10^{-2}$ in HBSS, and $1 \mathrm{ml}$ was injected ip into 9-month-old indicator C58 mice that had received $600 \mathrm{R} 24 \mathrm{hr}$ previously. To detect LDV activity each tumor cell extract also was injected ip $(1 \mathrm{ml})$ into 4- to 6-week-old BALB/c mice (5 mice/ assay). Five days later the plasma from individual mice was tested for lactic dehydrogenase (LDH) activity as described by Rowson and Mahy (12). A five-fold increase of $\mathrm{LDH}$ above normal levels was scored positive $(+)$ for LDV infection. The results in Table 2 show that the three $H-2^{\mathrm{k}}$ lymphoid tumors that elicited the disease were infected with LDV; the two $H-2^{\mathrm{k}}$ lymphoid tumors free of LDV did not. The two $H$ - $2^{\mathrm{d}}$ nonlymphoid tumors contaminated with LDV did not elicit the disease. The indicator mice that had received tumor extracts free of $\mathrm{LDV}$ (IbN and C58/J) were not immune to challenge by Ib cell extracts. 
The mice that had received LDV-positive, nonlymphoid, $H$-2d tumors were immune to line Ib LDV challenge. These results indicated that either LDV strains differed markedly in their neuropathogenicity, or that something associated with the $H-2^{\mathrm{k}}$ spleen cells of lymphoid tumors was required for LDV neuropathogenicity.

To test directly whether LDV was neuropathogenic to 9-month-old indicator C58 mice, strains of LDV virus were obtained that have been well characterized. Because our previous studies ( 7$)$, and the data in Table 2 , suggested that the C-type viruses abundant in C58 mice might have an effect on LDV neuropathogenicity, or that there might be a $H-2^{\mathrm{k}}$ haplotype association, virus stocks were prepared in both $\mathrm{C} 58 / \mathrm{Wm}$ $\left(H-2^{\mathrm{k}}\right)$ and $\mathrm{BALB} / \mathrm{cWm}\left(H-2^{\mathrm{d}}\right)$ mice for comparative tests. LDV stock strains [kindly provided by Drs. P. G. Plagemann, Department of Microbiology, Univ, of Minnesota (P-LDV); Dr. Vernon Riley, Fred Hutchinson Cancer Research Center, Washington (R-LDV); and Dr. A. L. Notkins, National Institute of Dental Research, National Institute of Health, Bethesda, Md. (N-LDV)] and line Ibderived virus (Ib-LDV) were passed three times serially in 2- to 3-month-old C58 and BALB mice. Passages were made by the ip injection of blood plasma specimens (1 $\mathrm{ml}$ ) at 24 -hr intervals. All stocks had an $\mathrm{ID}_{50}$ titer of $10^{9}-10^{10} / \mathrm{ml}$ plasma. The data in Table 3 established that the Ib-LDV strain was more neuropathogenic than the P-LDV, R-LDV, or N-LDV strains, and that the stocks of P-LDV, R-LDV, and N-LDV prepared in C58 mice were not markedly more neuropathogenic than those made in

TABLE 2

Induction of Paralytic Disease in Indicator C58 Mice By Tumor Cell Extracts

\begin{tabular}{|c|c|c|c|c|c|}
\hline $\begin{array}{l}\text { Tumor } \\
\text { cell line }\end{array}$ & Type of tumor & $\begin{array}{c}\text { Haplotype } \\
\text { of inbred host }\end{array}$ & $\begin{array}{l}\text { Incidence } \\
\text { of disease }{ }^{b}\end{array}$ & $\begin{array}{c}\text { LDV } \\
\text { associated } \\
\text { with tumor } \\
\text { cells }\end{array}$ & $\begin{array}{l}\text { Incidence of } \\
\text { disease in mice } \\
\text { challenged with } \\
\text { Ib cell extracts }\end{array}$ \\
\hline Line $\mathrm{Ib}$ & $\begin{array}{l}\text { Lymphocytic } \\
\text { leukemia }\end{array}$ & $\mathrm{C} 58 / \mathrm{Wm}\left(H-2^{\mathrm{k}}\right)$ & $20 / 20$ & + & \\
\hline K36 & $\begin{array}{l}\text { Lymphocytic } \\
\text { leukemia }\end{array}$ & $\mathrm{AKR} / \mathrm{J}\left(H-2^{\mathbf{k}}\right)$ & $5 / 12$ & + & $0 / 7$ \\
\hline Gardner & Lymphosareoma & $\mathrm{C} 3 \mathrm{H} / \mathrm{HeJ}\left(H-2^{\mathrm{k}}\right)$ & $12 / 12$ & + & \\
\hline $\mathrm{IbN}$ & $\begin{array}{l}\text { Lymphocytic } \\
\text { leukemia }\end{array}$ & $\mathrm{C} 58 / \mathrm{Wm}\left(H-2^{\mathrm{k}}\right)$ & $0 / 20$ & - & $20 / 20$ \\
\hline $\mathrm{C} 58 / \mathrm{J}$ & $\begin{array}{l}\text { Lymphocytic } \\
\text { leukemia }\end{array}$ & $\mathrm{C} 58 / \mathrm{Wm}\left(H-2^{\mathrm{k}}\right)$ & $0 / 9$ & - & $9 / 9$ \\
\hline WEHI-3B & $\begin{array}{l}\text { Myelomonucytic } \\
\text { leukemia }\end{array}$ & $\mathrm{BALB} / \mathrm{c} \mathrm{W}_{\mathrm{II}}\left(H-2^{\mathrm{d}}\right)$ & $0 / 14$ & + & $0 / 14$ \\
\hline $\begin{array}{l}\text { Harding- } \\
\text { Passey }\end{array}$ & Melanoma & $\mathrm{BALB} / \mathrm{cWm}\left(H-2^{\mathrm{d}}\right)$ & $0 / 14$ & + & $0 / 14$ \\
\hline
\end{tabular}

"The K36, Gardner, and C58/.J tumor cell lines were obtained from EG \& G Mason Research Institute, Worchester, Mass.; the remaining tumors were stock Michigan lines. IbN is an in vitro permanent line derived from Ib cells.

${ }^{b}$ Assays were done in X-irradiated (550 R) 7-to 9-month-old indicator C58 mice that were observed for paralysis for 60 days; paralytic disease was confirmed histopathologically. The mean time in days for paralysis was: Line $\mathrm{Ib}=15 ; \mathrm{K} 36=27$; Gardner $=20$.

" Mice that were free of disease over a 60 -day observation period were challenged by the ip injection $(1.0 \mathrm{ml})$ of line $\mathrm{Ib}$ cell extract $24 \mathrm{hr}$ after they received $600 \mathrm{R}$ of whole-body $\mathrm{X}$ irradiation. 


\section{TABLE 3}

COMPaRATIVE NEUROPATHOGENICITY OF LDV STRAINS

\begin{tabular}{|c|c|c|c|c|}
\hline $\begin{array}{l}\text { LDV } \\
\text { straint }^{t \prime}\end{array}$ & $\begin{array}{l}\text { Mouse } \\
\text { strain } \\
\text { for } \\
\text { passage }\end{array}$ & $\begin{array}{l}\text { Incidence } \\
\text { of disease }\end{array}$ & $\begin{array}{c}\text { Mean } \\
\text { days to } \\
\text { paralysis }\end{array}$ & $\begin{array}{l}\text { Incidence of } \\
\text { disease in } \\
\text { mice chal- } \\
\text { lenged with } \\
\text { Ib-LDV" }\end{array}$ \\
\hline \multirow[t]{2}{*}{ Ib-LDV } & C58 & $13 / 13$ & 15 & \\
\hline & BALB & $13 / 13$ & 15 & \\
\hline \multirow[t]{2}{*}{ P-LDV } & C58 & $10 / 16$ & 23 & $2 / 6$ \\
\hline & BALB & $5 / 15$ & 26 & $0 / 10$ \\
\hline \multirow[t]{2}{*}{ R-LDV } & $\mathrm{C} 58$ & $6 / 14$ & 26 & $0 / 8$ \\
\hline & BALB & $5 / 13$ & 27 & $0 / 8$ \\
\hline \multirow[t]{2}{*}{ N-LDV } & C58 & $12 / 15$ & 28 & $0 / 3$ \\
\hline & BALB & $8 / 15$ & 25 & $1 / 7$ \\
\hline
\end{tabular}

"Ib-LDV = LDV from Ib cells; P-LDV = Plagemann strain of LDV; R-LDV = Riley strain of LDV; N-LDV $=$ Notkins strain of LDV.

"Each 9-month-old indicator C58 mouse received $600 \mathrm{R}$ $24 \mathrm{hr}$ before the ip injection $(1 \mathrm{ml})$ of $10^{7} \mathrm{ID}_{\mathrm{sin}}$ of each stock virus.

"Mice were held for a 60-day observation period.

"Mice free of disease 60 days after initial virus injection received $600 \mathrm{R}$ and then were rechallenged with $10^{7} \mathrm{ID}_{50}$ of Ib-LDV. Control mice similarly held were fully susceptible to Ib-LDV-induced paralytic disease.

BALB mice. Mice that did not develop neurologic disease after P-LDV, R-LDV, or N-LDV infection were immune to Ib-LDV challenge.

Studied were done as described previously (4) to document that the histopathology of the paralytic disease elicited by LDV virus infection was the same as that elicited by line Ib cell-associated virus. Representative paralyzed and disease-free mice were killed, the vertebral column removed in toto, and fixed in $10 \%(\mathrm{v} / \mathrm{v})$ formalin-phosphate-buffered ( $\mathrm{pH}$ 7.2) $0.85 \% \mathrm{NaCl}$ solution. The entire column was decalcified and transverse slices of the spinal cord and vertebrae were taken at five levels as described previously (4). Sections were embedded in parafin, sectioned, and stained with hematoxylin and eosin. The histopathology of the disease elicited by LDV infection did not differ in any major way from that described previously (4). Mice free of clinical signs of disease did not have lesions suggestive of subclinical paralysis.
Serum protection tests were carried out to further confirm that LDV elicited neuroparalytic disease in indicator C58 mice. Antiserum was prepared from 2-month-old immunocompetent C58 mice that had received a single ip injection $(1 \mathrm{ml})$ of $10^{7} \mathrm{ID}_{50}$ of Ib-LDV or R-LDV. One month later blood was collected (retroorbital bleeding, $20 \mathrm{mice} /$ group), the serum separated, diluted 1:10 in $0.85 \% \mathrm{NaCl}$ solution (saline), and the immunoglobulins were precipitated with $45 \%$ saturation with ammonium sulfate. The precipitate and supernatant were dialyzed against saline $\left(4^{\circ}\right)$ for $24 \mathrm{hr}$ with a saline change every $6 \mathrm{hr}$. The volumes of both fractions were adjusted (HBSS) to the original serum volume. Antisera diluted either 1:10 or 1:25 were injected iv $(1 \mathrm{ml})$ into 7 -month-old indicator C58 mice that received $600 \mathrm{R} 24 \mathrm{hr}$ later. All mice were challenged $24 \mathrm{hr}$ later by ip injection of $10^{7} \mathrm{ID}_{50}$ of Ib-LDV. Table 4 shows that the immunoglobulin fraction obtained from the serum of mice immunized with either Ib-LDV or R-LDV

\section{TABLE 4}

Protection of Indicator Mice from Paralysis BY IMMUNE SERUM

\begin{tabular}{|c|c|c|c|}
\hline \multirow{2}{*}{$\begin{array}{l}\text { LDV strain used } \\
\text { to immunize } \\
\text { 2-month-old } \\
\text { normal C58 mice }\end{array}$} & \multirow{2}{*}{$\begin{array}{l}\text { Serum fraction } \\
\text { tested for } \\
\text { protection }\end{array}$} & \multicolumn{2}{|c|}{$\begin{array}{l}\text { Incidence of } \\
\text { disease in } \\
\text { mice that re- } \\
\text { ceived serum } \\
\text { fraction } \\
\text { diluted: }\end{array}$} \\
\hline & & $1: 10$ & $1: 25$ \\
\hline \multirow[t]{3}{*}{ Ib-LDV } & whole serum & $5 / 32$ & \\
\hline & immunoglobulins & $3 / 13$ & \\
\hline & supernatant & $9 / 10$ & \\
\hline \multirow[t]{3}{*}{ R-LDV } & whole serum & $1 / 12$ & \\
\hline & immunoglobulins & $0 / 13$ & $0 / 17$ \\
\hline & supernatant & $0 / 12$ & $10 / 14$ \\
\hline Normal serum & whole serum & $15 / 15$ & \\
\hline
\end{tabular}

a Serum fractions were injected iv $(1.0 \mathrm{ml})$ into 7 -month-old indicator C58 mice. The next day they received $600 \mathrm{R}$ of whole-body $\mathrm{X}$ irradiation. Twentyfour hours later they were challenged by the ip injection of $10^{7} \mathrm{ID}_{50}$ of Ib-LDV. Mice were scored for paralysis over a 30 -day period. 
protected Ib-LDV-challenged mice from the disease.

The evidence implicating LDV as an essential etiologic factor in the age-dependent paralytic neurologic disease that occurs in the naturally susceptible C58 strain is reasonably sound. LDV derived from Ib cells elicited the disease; Ib cells freed of LDV by growth in vitro (IbN) did not. C58 mice inoculated with LDV strains of low neuropathogenicity were immune when challenged with Ib-LDV. Serum from mice immunized with Ib-LDV or R-LDV protected indicator mice from Ib-LDV challenge. Well-characterized strains of LDV elicited the specific disease syndrome as proven by the appropriate histologic studies. The peak activity of virus in serum was associated with a $1.17 \mathrm{~g} / \mathrm{ml}$ buoyant density fraction in $\mathrm{CsCl}$ gradients, serum titers $24 \mathrm{hr}$ after infection were of the order of $10^{9}-10^{10} \mathrm{ID}_{50} / \mathrm{ml}$, and LDV strains of low neuropathogenicity (R-LDV) interfered with the neuropathogenicity of Ib-LDV (unpublished data). These results are consistent with the conclusion that the neuropathogenic agent was in fact LDV. Our results are in accord with those reported in parallel studies by Martinez et al. (Ref. (8) and personal communication).

In the described experimental model, as in other multifactorial diseases such as those that occur in NZB mice (13), a number of etiologic factors must converge to elicit pathologic changes. It is within this context that LDV is to be considered a neuropathogenic agent in the naturally susceptible C58 strain. We now have identified (reviewed in 7 ) four conditions that must be met for neuroparalytic disease to occur in the naturally susceptible C58 strain. The first is an age-dependent loss in T-cell functions $(6,7)$ that includes the failure to develop a protective response to line Ib transplantable leukemia (3), a decrease in the capacity of the spleen cells from old mice to undergo a blastogenic response to $\mathrm{T}$-cell mitogens (14) and to produce antibodies to sheep erythrocytes (5). We report here the second requirement, viz, infection by neuropathogenic strains of LDV. Two additional factors are of equivalent importance. Detailed genetic studies have shown (Ref. ( $y$ ) and unpublished data) that susceptibility is not $\mathrm{H}-2$ linked but appears to be regulated primarily by the Fv-1 locus (15). Moreover, only those mouse strains that contain multiple copies of $\mathrm{N}$-tropic C-type retroviruses in their genomes (16) and that are permissive for $\mathrm{N}$-tropic retrovirus replication $\left(\mathrm{Fv}-1^{\mathrm{n} / \mathrm{n}}\right)$ appear to be susceptible. Other genetic factors also are involved in natural susceptibility or resistance (unpublished data). Such results suggest that dual infection by LDV and N-tropic C-type retroviruses is required to elicit the disease. The paradox is that both C-type viruses (3) and LDV (8) are abundant in the central nervous system of C58 mice as well as in most other tissues. Since neither LDV nor C-type viruses ordinarily are cytopathic, it is not clear whether motor neuron destruction results from sequential or dual infection by these viruses or is mediated immunologically. The complexities of these problems are discussed in the cogent review by oldstone et al. (17). Nevertheless, the findings reported here suggest two considerations of possible importance for future work: that the use of immunosuppressed genetically susceptible animals may aid in the detection of viruses in the slowly progressive neurologic diseases of suspected virus etiology; and that in some of these diseases infection by a common ubiquitous virus combined with endogenous virus infection may elicit a specific disease syndrome in a genetically susceptible host.

\section{ACKNOWLEDGMENTS}

This study was supported by Grant S07-RR-05383 from the National Institutes of Health. United States Public Health Service. Larry R. Pease is the recipient of a postfellowship from the Damon Runyon-Walter Winchell Cancer Fund, Grant I)RC-190-FT.

\section{REFERENCES}

1. Lukasewycz, O. A., Duffey, P. S., and MURPhy, W. H., J. Immunol. 116, 976-981 (1976).

2. Lukasewycz, O. A., and Frelinger, J. A., $J$. Exp. Med. 145, 1077-1081 (1977).

3. Murphy, W. H., TAM, M. R., LANZI, R. L., Abell, M. R., and Kauffman, C., Cancer Res. 30, 1612-1622 (1970). 
4. Lawton, J. W. M., and Murphy, W. H., Arch. Neurol. 28, 367-370 (1973).

5. Duffey, P. S., Martinez, D., Abrams, G. D., and MURPHY, W. H., J. Immunol. 116, 475481 (1976).

6. Murphy, W. H., In "Progress in Neurological Research" (P. O. Behan and C. F. Rose, eds.), p. 175. Pitman, London, 1979.

7. Murphy, W. H., Nawrocki, J. F., and Pease, L. R., In "Animal Models of Neurologic Disease" (P. O. Behan and C. F. Rose, eds.). Pitman, London, 1980, in press.

8. Martinez, D., Wolanski, B., Tytell, A. A., and Devlin, R. G., Infec. Immun. 23, $133-139$ (1979).

9. Taylor M. J., and MacDowell, E. C., Cancer Res. 9, 144-149 (1949).

10. Parker, J. C., Tennant, R. W., and Ward, T. G., In "Viruses of Laboratory Rodents"
(Holdenreid, ed.), pp. 25-36. U.S. Govt. Printing Office, Washington, D.C., 1966.

11. Sager, M. A., Lawton, J. W. M., and Murphy, W. H., J. Immunol. 110, 219-226 (1973).

12. Rowson, K. E. K., and Maнy, B. W. J., "Lactic Dehydrogenase Virus," p. 102. SpringerVerlag, New York, 1975.

13. Talal, N., and Stineberg, A. D., Curr. Top. Microbiol. Immunol. 64, 79-103 (1974).

14. Lawton, J. W. M., and Murphy, W. H., Immunology 26, 1093-1099 (1974).

15. Steeves, R., and Lilly, F., Annu. Rev. Genet. 11, $277-296$ (1977).

16. Lowy, D. R., Chattopadhyay, S. K., Teich, N. M., Rowe, W. P., and Levine, A. S., Proc. Nat. Acad. Sci. USA 71,3555-3559(1974).

17. Oldstone, M. B. A., Lampert, P. W., Lee, S., and Dixon, F. J., Amer. J. Pathol. 88, $193-212$ (1977). 